\title{
Organizational Commitment and Turnover Intention in Low-Skilled Immigrant Workers in Thailand: An Empirical Assessment of Need Satisfaction, Job Satisfaction and Overall Life Satisfaction Factors
}

\author{
Kevalin Puangyoykeaw ${ }^{1} \&$ Yuko Nishide ${ }^{1}$ \\ ${ }^{1}$ Graduate School of Economics and Management, Tohoku University, Japan \\ Correspondence: Kevalin Puangyoykeaw, Graduate School of Economics and Management, Tohoku University, \\ Room 31, 6-14-15, Higashi-Sendai, Miyagino-ku, Sendai, Japan. Tel: 81-90-2982-2531. E-mail: \\ kevalin.p@gmail.com
}

Received: March 13, 2015

Accepted: March 20, 2015

Online Published: April 20, 2015

doi:10.5539/ijbm.v10n5p98

URL: http://dx.doi.org/10.5539/ijbm.v10n5p98

\begin{abstract}
As a result of its pace of development, Thailand is now facing a shortage of low-skilled labour, especially in labour-intensive industries. An influx of workers from neighbouring countries, especially Myanmar, is now substituting for low-skilled nationals. The challenge of how organizations can retain and motivate low-skilled workers remains a major issue. The scarce literature and little focus on how low-skilled workers can be managed have given rise to this paper. In this paper, we aim to examine the effect of need satisfaction, job satisfaction and life satisfaction on organizational commitment and turnover intention. To gain an understanding of the variables affecting the organizational commitment and turnover intention of low-skilled workers, which largely remain unexplained, we draw on 400 samples from 13 randomly selected Thai seafood processing factories in Samut Sakhon Province. The data were analysed using structural equation modelling with exploratory factor analysis to confirm the path diagram. The results of this paper provide additional evidence in support of existing literature, need satisfaction and life satisfaction demonstrated positive relationships with organizational commitment at significant level $\alpha=0.01$, as well as evidence that contradicts current theories, job satisfaction showed no significant relationship with organizational commitment and, interestingly, turnover intention in low-skilled worker showed a positive relationship with need satisfaction. This paper aims to provide a better understanding of how employers can efficiently and effectively motivate and retain low-skilled workers in Thailand.
\end{abstract}

Keywords: organizational commitment, turnover intention, low-skilled workers, Myanmar, Thailand

\section{Introduction}

An organization's labour force is an important asset as its contribution is essential to firm success. The complexity of human behaviour and the rationale behind individual acts are well known as each person has his or her own agenda and goals. Managing the labour force is thus a challenging task for all organizations. A key aim for organizations is to retain committed and potentially good performers as their loss would mean considerable cost to the firm. What makes an employee leave or intend to leave is a major question for any company (Mahdi et al., 2012). When a worker leaves an organization, there is a loss to the company both economically and in terms of time as all the effort invested in the employee is lost forever. Examples of turnover costs include opportunity costs, retraining costs, reselection cost and decreased morale among other employees (Cho, Johanson, \& Guchait, 2009).

Having committed employees is beneficial to the firm. Aamodt (2007) suggests that employees who are satisfied and committed are more likely to attend work, stay with an organization, arrive at work on time, perform well and engage in positive behaviours helpful to the organization. Simply put, committed employees tend to act more productively and positively towards an organization. Therefore, employers should aim to increase their employees' level of commitment and reduce turnover intention in order to improve the sustainability and morale of the labour force.

Extensive studies have been conducted on organizational commitment and turnover intention in skilled workers. However, there is still a lack of concrete evidence and support concerning the factors that influence commitment and turnover intention. Furthermore, only a limited amount of research has been undertaken in the context of 
low-skilled workers. The examples of low-skilled worker studies found by the author are the study by Aworemi, Abdul-Azeez, and Durowoju (2011) studied the motivational factors of low-skilled worker in Nigeria, Dawal, Taha, \& Ismail (2009) studied job satisfaction among shop floor employees in automotive industry in Malaysia, Salami (2008) studied demographic and psychological factors that affecting organizational commitment among industrial workers in Nigeria, and Puangyoykeaw and Nishide (2014) studied the need of low-skilled Myanmar worker in Thailand. Nonetheless, the study of human resource management in low-skilled workers remains relatively under-explored (Forde \& MacKenzie, 2009).

Low-skilled workers are important to labour-intensive industries. Such workers are employed by organizations to benefit from low labour costs. As low-skilled labour is characterized by limited skills and low switching costs, the turnover issue is one of the greatest challenges for labour-intensive environments such as factories. Managing a low-skilled labour force is a challenging task for managers and companies because of the workers' limited skills and competences, meaning that a limited number of motivational techniques and tools can be implemented to foster employee retention (Puangyoykeaw \& Nishide, 2014). However, low-skilled workers, even with their limited skills, can accumulate expertise over time.

The dearth of research concerning employee commitment and turnover intention in low-skilled workers necessitates the study of this paper, which explores the factors that could influence an increase in commitment and a reduction in turnover intention in low-skilled workers. Specifically, this paper examines organizational commitment and turnover intention among low-skilled workers in relation to: (1) need satisfaction, (2) job satisfaction and (3) life satisfaction. These aspects of satisfaction, resulting in a positive psychological state of mind, are considered to play a prominent role in influencing positive employee behaviours. Thus, these factors are investigated in depth to explore which variables are major determinants in explaining organizational commitment and turnover intention.

The paper examines these issues through an empirical study of Myanmar workers in Thailand. Approximately $90 \%$ of the low-skilled jobs in the Thai seafood processing industry are now done by workers from Myanmar. With the growing pace of development in Thailand, local Thai citizens are no longer interested in working in 3D (dirty, dangerous and demeaning) industries, resulting in a shortage of low-skilled workers - a common phenomenon for growing economies - and hence an increase in importing low-skilled workers from elsewhere. This empirical study is based in Samut Sakhon (in the province of the same name), also known as "Little Burma", a coastal town which is home to Thailand's seafood processing factories. The paper draws on data from a survey of 400 Myanmar workers in 13 randomly selected factories in the area. To the author's knowledge, this is the first study to focus on Myanmar immigrant workers in Thailand from a human resource management perspective.

The main purposes of this study are: (1) to explore the relationship between employees' need satisfaction, job satisfaction and overall life satisfaction and organizational commitment and turnover intention; (2) to identify factors that have predictive effects and the greatest impact on organizational commitment and turnover intention among low-skilled workers from Myanmar in Thailand. The aim is further to establish causal relationships among these tested variables. Through understanding the relationships between factors influencing organizational commitment and turnover intention and how they do so in this context, the study could add new knowledge regarding low-skilled workers and help improve organizational practices to increase employee organizational commitment and retain valuable workers.

It is therefore hoped that the results of this empirical study will enhance the existing body of literature by considering aspects that have not yet been examined and that the research will provide a better understanding of how employers can motivate and retain low-skilled workers. By understanding what variables are connected to organizational commitment and turnover intention, organizations can be helped to increase levels of commitment in their employees and efficiently and effectively reduce turnover. Furthermore, it is hoped that the results could provide valuable input for the creation of organizational management policy and human resource management policy in low-skilled labour contexts.

\section{Literature Review and Hypotheses}

In this section, Meyer and Allen's three-component model of commitment, the turnover intention concept, Maslow's hierarchy of needs, Herzberg's motivation-hygiene theory and the notion of life satisfaction are discussed in detail and the research hypotheses are developed.

\subsection{Organizational Commitment}

Organizational commitment as defined by Meyer and Allen $(1991,1997)$ is a psychological state of mind that reflects a desire, need and obligation to maintain membership within an organization. In 1991, Meyer and Allen 
introduced the Three-Component Model of organizational commitment, a model which is widely accepted and has gained popularity as a dominant predictor of organizational commitment. The three components of the model are affective commitment, continuance commitment and normative commitment. The model has been used by researchers to predict important employee outcomes, such as turnover, job performance and absenteeism (Meyer, Stanley, Herscovitch, \& Topolnytsky, 2002).

Affective commitment, as the term suggests, is an emotionally based psychological state that drives employees to stay with a particular organization out of love or affection. This could be the result of positive past work-related behaviours (Meyer et al., 2002) and is the preferred form of commitment for companies (Velickovic et al., 2014). Employees stay with the employer because of their harmonious relationship with the company and their positive attitude towards the goals and values of the organization for which they are currently working (Lumley, Coetzee, Tladinyane, \& Ferreira, 2011). Put simply, employees "want" to stay with the organization based on their emotional ties to it.

Continuance commitment is a person's decision to stay with an organization based on weighing the cost associated with leaving the company. The primary antecedents of continuance commitment are a perceived lack of alternatives or an inability to transfer skills and education to another organization (Meyer et al., 2002). This appears to be the least beneficial form of commitment as it represents a lose-lose situation for both the employee and the organization, with the employee remaining in an uncomfortable position out of need or lack of alternatives. Employees who stay based on continuance commitment can potentially contaminate the work group (McMahon, 2007).

Normative commitment is when an employee stays with an organization out of a sense of obligation and responsibility. They feel that retaining membership of a particular organization is the right thing to do. The feeling of indebtedness is an example of normative commitment. Normative commitment can be developed when an organization offers special treatment, e.g. advance payments, paying for child tuition and special needs and training. Employees develop the sense that they "ought" to stay with the organization.

The three types of commitment are not mutually exclusive (Herscovitch \& Meyer, 2002; Solinger, Van Olffen, \& Roe, 2008). The study by Puangyoykeaw (2014) and Van Breugel, Van Olffen, and Ollie (2005) founded low-skilled workers find affective commitment mostly important, followed by normative component and continuance component. Organizational commitment has been shown to exhibit a positive relationship with need satisfaction, job satisfaction and life satisfaction: the greater employees' satisfaction, the greater their commitment.

\subsection{Turnover Intention}

Turnover intention is an employee's predetermination to withdraw and leave an organization, not the actual separation from the organization itself. According to Cotton and Tuttle (1986), turnover intention refers to an individual's perceived probability of staying with or leaving an employing organization. Turnover intention can result in losses to a firm, through the loss of talented human capital and the possible leakage of firm know-how to competitors (Khanin, 2013).

Barak, Nissly, and Levin (2001) propose that it is useful to measure turnover intention rather than actual turnover because one's intention to act can be the immediate determinant of that behaviour. Turnover intention can be a good proxy for measuring actual turnover because the latter can be difficult to measure (Hayes et al., 2006). Numerous studies (e.g., Kalliath \& Beck, 2001; Kramer, Callister, \& Turban, 1995; Mahdi et al., 2012; Price \& Mueller, 1981) have been conducted to understand what determines employees' turnover intentions. Nonetheless, a single, broadly accepted, comprehensive model of turnover is still lacking (Gieter, Hofmans, \& Pepermans, 2011). However, turnover intention has been tied closely to satisfaction. Thus, the more satisfied employees are with their jobs, the less likely they are to leave them (Hayes et al., 2006).

\subsection{Need Satisfaction}

For humans to survive physiologically, we need oxygen, food, water, shelter, clothing and sleep. However, humans grow, adapt, thrive and develop psychological understandings that result in requirements far beyond these basic physiological needs. One of the most basic and well-known theories in the sociological field to attempt to categorize human needs is Maslow's $(1954,1968)$ hierarchy of needs. The hierarchy describes the stages of growth in humans. The five levels of needs in the hierarchy, starting from the base and progressing to the apex, are physiological needs, safety and security needs, love and belonging needs, self-esteem needs and self-actualization needs. The five categories of needs function like a staircase in that a person cannot progress to a higher level unless the lower needs are met (Freitas \& Leonard, 2011; Hamel, Leclerc, \& Lefrancois, 2003). 
Betz (1984) pointed out that more than one level of need could be motivators at a given point in time. However, the strongest motivator remains the lowest unsatisfied need (Aworemi, Abdul-Azeez, \& Durowoju, 2011). A study conducted by Puangyoykeaw and Nishide (2014) examined the needs of Myanmar workers in Thailand found that the ranking is largely accords with Maslow's theory, that is physiological needs and safety and security needs are ranked as most important for low-skilled workers.

By understanding what employees need, their need satisfaction can be improved. Ahmed and Alvi (1987) found that organizations which fulfil their employees' needs are able to enhance their commitment level. Moreover, need satisfaction can drive the work attitude of employees, helping them to achieve their goals (Rajasekhar \& Vijayasree, 2012). Bourantas (1988) found that employees' organizational commitment is determined more by the satisfaction of higher-order needs than of lower-order needs. This is in line with Maslow's (1970) research which suggested the existence of a positive relationship between commitment and need satisfaction. This study examines which needs have the greatest impact on organizational commitment and turnover intention.

Based on the above, the following hypotheses are constructed:

Hypothesis 1 Need satisfaction is positively and significantly related to organizational commitment.

Hypothesis 2 Need satisfaction is negatively and significantly related to turnover intention.

\subsection{Job Satisfaction}

Job satisfaction is the level of satisfaction workers feel with their jobs or the content of their jobs. Job satisfaction has been the focus of academic attention as an important variable in understanding organizational behaviour. Researchers believe that job satisfaction can influence work productivity, employee turnover, absenteeism and life satisfaction (Spector, 2008). Several studies have found that job satisfaction has a positive relationship with all three dimensions of organizational commitment and an inverse relationship with turnover intention (Aydogdu \& Asikgil, 2011; Mahdi et al., 2012; Yucel, 2012). Moreover, research has found that job satisfaction may be the most important construct in attempting to understand turnover (Ghiselli, Lopa, \& Bai, 2001). It is not surprising that satisfied employees tend to be committed to an organization as well as having less intention to leave.

The most prominent theory related to job satisfaction is Herzberg's $(1991,1996)$ motivation-hygiene theory. This is a widely accepted and extensively tested theory in evaluating employee job satisfaction. According to Herzberg, different job aspects can result in employees' satisfaction and dissatisfaction (Wright, 1989). Herzberg classifies the possible factors affected job satisfaction into two groups: hygiene factors and motivators. Hygiene factors concern aspects surrounding the job, for example pay, fringe benefits, interpersonal relationships with supervisors and co-workers, and surrounding conditions. These factors represent those needs the fulfilment of which is mandatory from the perspective of employees. Therefore, working conditions related to these factors that are deficient will cause dissatisfaction, but sufficient provision will not motivate or result in satisfaction (Herzberg, 1971; Herzberg, Mausner, \& Bloch Snyderman, 2005). Motivators are aspects that are related to the job itself. Examples of such factors are recognition, achievement, responsibility, advancement, and the work itself. As the term suggests, the presence of motivators at work will increase employee motivation, but a lack of these factors will not necessarily cause dissatisfaction. Understanding these aspects of job satisfaction is useful to organizations in identifying areas for improvement and enhancing employee satisfaction (Saari \& Judge, 2004; Westlund \& Hannon, 2008).

Based on the above, the following hypotheses are derived:

Hypothesis 3 Job satisfaction is positively and significantly related to organizational commitment.

Hypothesis 4 Job satisfaction is negatively and significantly related to turnover intention.

\subsection{Life Satisfaction}

Life satisfaction has long been linked to employees' work behaviours. Satisfied individuals contribute better and have a more positive attitude. Judge, Thoresen, Bono, and Patton's (2001) meta-analysis of research on the link between job satisfaction and performance suggests that the job performance of managers who are satisfied with their jobs is higher than that of workers who are less satisfied and that life satisfaction moderates the relationship between job satisfaction and performance. Thus, there is a relationship between life satisfaction and organizational commitment. A high level of organizational commitment is related to greater life satisfaction and vice versa (Kacmar, Carlson, \& Brymer, 1999). Therefore, it can be suggested that individuals who are satisfied with their lives will be less likely to leave their jobs. Thus, the following hypotheses are developed:

Hypothesis 5 Life satisfaction is positively and significantly related to organizational commitment. 
Hypothesis 6 Life satisfaction is negatively and significantly related to turnover intention.

The hypothesized relationships between the study variables are illustrated in a conceptual framework in Figure 1.

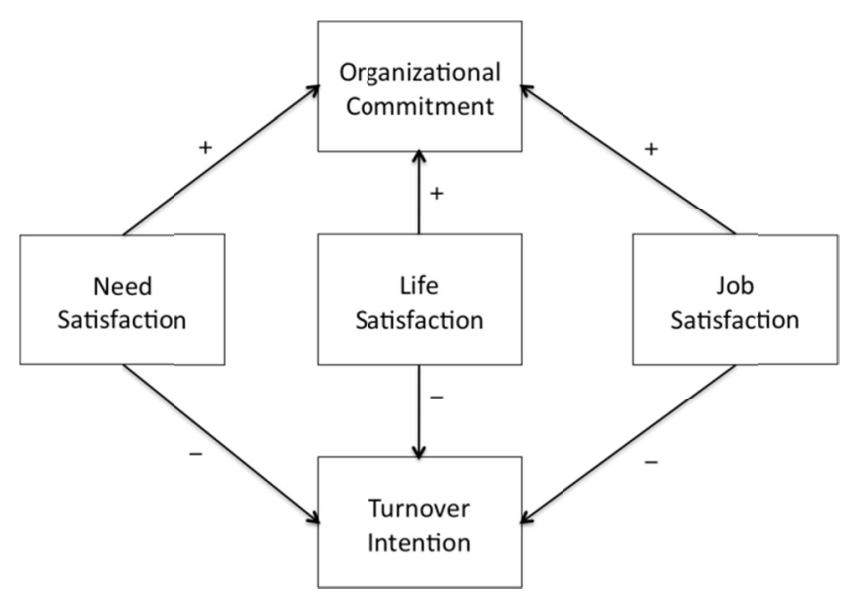

Figure 1. Hypothesized relationship between need satisfaction, job satisfaction, life satisfaction, organizational commitment and turnover intention

\section{Methods}

\subsection{Research Sample and Procedure}

Fieldwork was undertaken using questionnaires to obtain the data through convenience sampling. The sample was randomly selected from 13 of the 126 seafood processing factories granted immigrant quotas in Samut Sakhon, or "Little Burma". According to a Thailand Development Research Institute report (2007), studying demand for immigrant workers in Thailand, the country is highly dependent on immigrant workers, the highest demand being in fishery-related industries. Thus, this study focuses on the seafood processing industry.

Using Taro Yamane's (1967) formula to determine the suitable sample size to represent the whole population, with a total of 72,565 immigrant workers registered with the Samut Sakhon Office Workers' Department at year end 2013, at least 398 samples should be collected (95\% confidence level). This number was rounded up and a total of 400 questionnaires were distributed to Myanmar workers at the 13 selected seafood processing factories in Samut Sakhon.

\subsection{Participants}

The demographic data for the study participants are summarized in Table 1. As can be seen, the majority of workers in the study were male, aged 20-30 years old, married and educated to middle school level. They were predominantly employed on a part-time basis and had been with their current employer and resident in Thailand for 1-3 years.

Table 1. Participants' demographic data

\begin{tabular}{lcc}
\hline Variable & $\mathrm{N}$ & $\%$ \\
\hline Gender & & \\
Male & 247 & 61.75 \\
Female & 153 & 38.25 \\
Age & & \\
$<20$ years & 24 & 6 \\
$20-25$ years & 107 & 26.75 \\
$26-30$ years & 141 & 35.25 \\
$31-35$ years & 84 & 21 \\
$>36$ years & 44 & 1 \\
\hline
\end{tabular}




\begin{tabular}{|c|c|c|}
\hline \multicolumn{3}{|l|}{ Marital/family status } \\
\hline Single & 179 & 44.75 \\
\hline Married with children & 111 & 27.75 \\
\hline Married without children & 99 & 24.75 \\
\hline Divorced & 11 & 2.75 \\
\hline \multicolumn{3}{|l|}{ Education } \\
\hline Completed primary school & 83 & 20.75 \\
\hline Completed middle school & 229 & 57.25 \\
\hline Completed high school & 49 & 12.25 \\
\hline Bachelor degree & 9 & 2.25 \\
\hline No formal education & 30 & 7.5 \\
\hline \multicolumn{3}{|l|}{ Employment status } \\
\hline Part time & 313 & 78.25 \\
\hline Full time & 87 & 21.75 \\
\hline \multicolumn{3}{|c|}{ Length of employment with current employer } \\
\hline$<1$ year & 35 & 8.75 \\
\hline $1-2$ years & 105 & 26.25 \\
\hline $2-3$ years & 148 & 37 \\
\hline $3-5$ years & 70 & 17.5 \\
\hline $5-10$ years & 38 & 9.5 \\
\hline$>10$ years & 4 & 1 \\
\hline \multicolumn{3}{|c|}{ Length of residence in Thailand } \\
\hline$<1$ year & 17 & 4.25 \\
\hline $1-2$ years & 66 & 16.5 \\
\hline $2-3$ years & 132 & 33 \\
\hline $3-5$ years & 74 & 18.5 \\
\hline $5-10$ years & 94 & 23.5 \\
\hline$>10$ years & 17 & 4.25 \\
\hline
\end{tabular}

\subsection{Questionnaire Instrument}

The questions used in the questionnaire were carefully selected from various past studies and the literature. The questionnaire was translated from English into Burmese by a translator. To ensure the accuracy of the translation, another translator was asked to back-translate the questionnaire into English. Pilot testing was conducted before gathering the data. After obtaining feedback, the questionnaire was modified and its reliability tested: the Cronbach's alpha coefficient was .844, showing good internal consistency overall and the measurement scales for organizational commitment, need satisfaction and job satisfaction had Cronbach's alpha coefficients of $.528, .730$ and .765 , respectively. Taking into account the possibly limited literacy skills of the Myanmar respondents and time constraints, the questionnaire was designed to be as precise and as concise as possible. The scales of measurement for each construct are detailed in turn in the following paragraphs.

Organizational commitment. Commitment to the organization was measured on a five-point Likert scale $(5=$ strongly agree; 1 = strongly disagree) using three items: "I am a very happy member of this organization", representing affective commitment; "It would be very hard for me to leave this organization right now, even if I wanted to", representing continuance commitment; "I feel that I owe this organization quite a bit because of what it has given me", representing normative commitment. These statements were selected from the list of items in the revised commitment scale developed by Jaros (1997).

Turnover intention. To measure the turnover intention of Myanmar immigrant workers, the respondents were asked to respond to the statement "Nevertheless, I often think about quitting" on a five-point Likert scale anchored at 5 "strongly agree" and 1 "strongly disagree". The statement was adopted from the study of Khatri, Fern, and Budhwar (2001).

Need satisfaction. Ten statements were included to represent Maslow's hierarchy of needs - two statements for each level - measuring the employees' need satisfaction, again using a five-point Likert-type scale $(5$ = very satisfied, 1 = very dissatisfied). The statements used were selected from the studies of Dillman (2000), Freitas and Leonard (2011) and Maslow (1954), as summarized in Table 2. 
Table 2. Summary of selected statements

\begin{tabular}{|c|c|c|c|}
\hline \multicolumn{2}{|c|}{ NEED SATISFACTION ITEMS } & \multicolumn{2}{|c|}{ JOB SATISFACTION ITEMS } \\
\hline N1.1 & $\begin{array}{l}\text { The ability to provide food, clothing and shelter for } \\
\text { you and your significant others }\end{array}$ & JS1 & I feel I am being paid a fair amount for the work I do. \\
\hline $\mathrm{N} 1.2$ & The opportunity to be financially independent & JS2 & $\begin{array}{l}\text { Those who do well on the job stand a fair chance of being } \\
\text { promoted. }\end{array}$ \\
\hline $\mathrm{N} 2.1$ & $\begin{array}{l}\text { The ability to ensure a safe home environment for you } \\
\text { and your significant others }\end{array}$ & JS3 & My supervisor is quite competent in doing his/her job. \\
\hline $\mathrm{N} 2.2$ & The opportunity to be in a safe working environment & JS4 & I am satisfied with the benefits I receive. \\
\hline N3.1 & The ability to feel loved by your significant others & JS5 & I feel my efforts are rewarded in the way they should be. \\
\hline N3.2 & The opportunity to feel part of a team/group/society & JS6 & I believe there is a safe working environment at my workplace. \\
\hline N4.1 & The ability to achieve a sense of accomplishment & JS7 & I like the people I work with. \\
\hline N4.2 & The opportunity to achieve personal satisfaction & JS8 & I understand exactly what I am supposed to do. \\
\hline N5.1 & The opportunity to contribute to society & JS9 & I always finish my work successfully. \\
\hline N5.2 & The capacity to inspire members of society & JS10 & Work assignments are fully explained and easy to understand. \\
\hline
\end{tabular}

Job satisfaction. Items derived from the Job Satisfaction Survey (JSS) developed by Spector $(1985,1996)$ were chosen for this study. These statements help to measure employees' satisfaction related to different various job dimensions. Ten facets of job satisfaction are measured, namely: pay, promotion, supervision, fringe benefits, recognition, operating conditions, co-workers, nature of the work, responsibility and communication. The statements used are given in Table 2. Each item was rated on a five-point Likert scale anchored at 5 "strongly agree" and 1 "strongly disagree".

Life satisfaction. The workers' satisfaction with life in Thailand was measured using a single statement "I am very satisfied with my life as it is at the moment", drawn from Campbell, Converse, and Rodger's (1976) work at the University of Michigan Survey Research Center. The validity of this statement has been tested and it is considered an adequate question to ascertain employee life satisfaction. The responses to the statement are given on a five-point Likert scale ( $5=$ strongly agree; $1=$ strongly disagree $)$.

\subsection{Statistical Analysis}

Structural equation modelling (SEM) was used to test the research hypotheses. SEM is useful to demonstrate the relationships between several variables at once (interrelationships, direct and indirect paths) in an easy to understand graphical model, helping to explain the causal relationships between the variables tested. The AMOS program, a popular SEM program, was used for this study. Confirmatory factor analysis (CFA) was conducted to test model fit until a well-fitted measurement model was obtained. In terms of the sample size for SEM, the sample of 400 was more than adequate to satisfy the values of Hoelter .05 and Hoelter .01 required for hypothesis testing at the $95 \%$ and $99 \%$ confidence intervals respectively.

\section{Results}

To test the hypotheses, the path coefficient diagram shown in Figure 2 was drawn as an initial modelling of the relationships between need satisfaction, job satisfaction, life satisfaction, organizational commitment and turnover intention. The model fit analysis shows a $\chi 2$ value of 1146.325 with 271 degrees of freedom, returning a probability value of .000 . The $\chi 2 / \mathrm{df}$ represents the degree of fit between the model and the data. With the large sample size used in this study, it is difficult to obtain a non-significant p-value. The fit indices are therefore used as adjuncts to the $\chi^{2}$ test to evaluate further the adequacy of the fit of the model. The goodness-of-fit index (GFI) of .805, the comparative fit index (CFI) of .573, the Tucker-Lewis Index (TLI) of .528, the incremental fit index (IFI) of .579, and the root mean square error of approximation (RMSEA) of .090 show the initial model does not provide a good fit to the data and modification was thus required. 


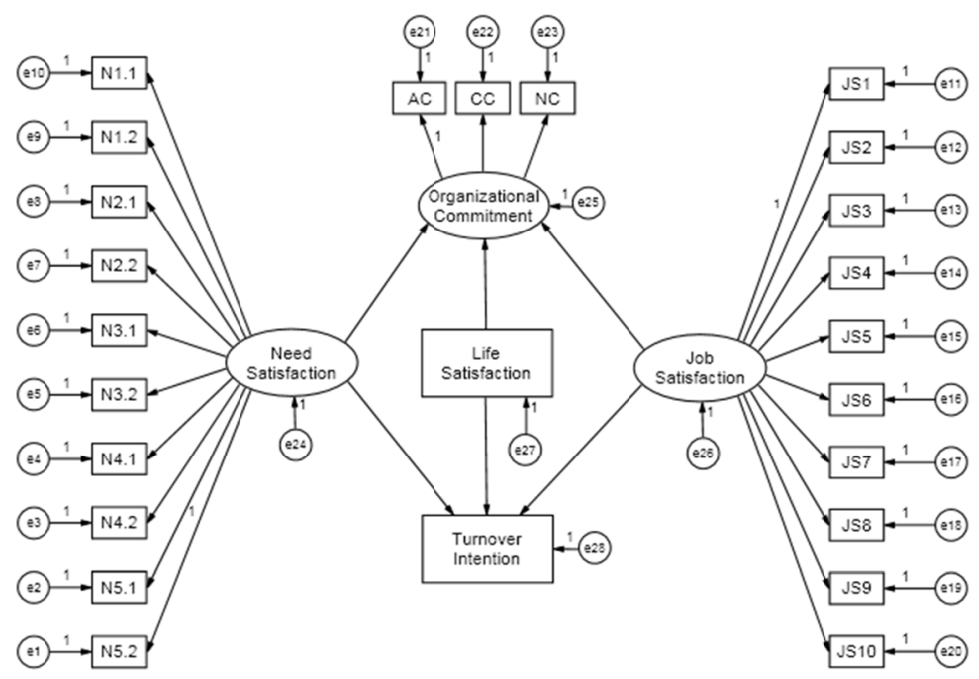

Figure 2. Path diagram: initial modelling of the relationships between need satisfaction, job satisfaction, life satisfaction, organizational commitment and turnover intention

Figure 3 illustrates the results of the first attempt at model modification. The modification indices suggested inter-correlated covariance among need, job and life satisfaction to increase the model fit. This is understandable as when employees are satisfied that their needs are being met, they are likely to be satisfied with life and possibly also their work, as well as the other way round. The modification indices also advise linking the needs items in the same level of Maslow's hierarchy. Finally, the indices indicate the elimination of the latent variables for organizational commitment and linking need satisfaction, job satisfaction and life satisfaction directly to affective commitment, continuance commitment and normative commitment. This model shows a $\chi 2$ value of 754.412 with 258 degrees of freedom, returning a probability value of .000 with $\chi 2 / \mathrm{df}$ of 2.924 . The model fit indices are as follows: $\mathrm{GFI}=.865 ; \mathrm{CFI}=.758$; $\mathrm{TLI}=.719$; $\mathrm{IFI}=.763$; $\mathrm{RMSEA}=.069$. This model shows a much better fit to the observed data. However, with a GFI still less than .9, there is further room for improvement.

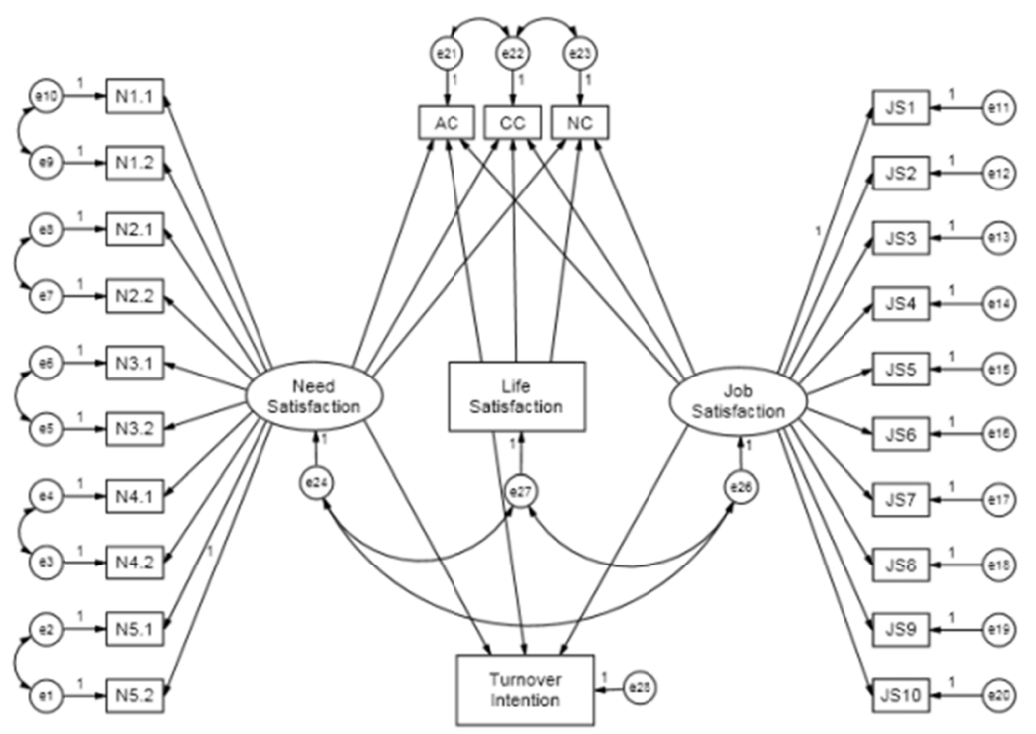

Figure 3. First modification of the model

Looking at the measurement loads of each item, less significant variables can be eliminated to improve the model. The first item to be deleted is the need item N3.2 (the opportunity to feel part of a team/group/society). As low-skilled jobs are characterized as based on individual performance on the production line, the need for 
teamwork is understandably insignificant. N1.1 and N2.2 are also deleted from the model. The ability to provide food, clothing and shelter and an opportunity to be in a safe working environment are not as significant as being financially independent and ensuring a safe home environment (N1.2 and N2.1). For job satisfaction, there are three items with small loads: the lowest three items are JS8 (nature of work), JS9 (responsibility) and JS10 (communication). This new model shows a $\chi^{2}$ value of 361.920 with 138 degrees of freedom, returning a probability value of .000 with a $\chi 2 / \mathrm{df}$ of 2.623 , an acceptable value. The fit indices are all acceptable: GFI=.913; $\mathrm{CFI}=.841 ; \mathrm{TLI}=.802 ; \mathrm{IFI}=.844 ; \mathrm{RMSEA}=.064$. Thus, this model can be deemed a good fit to the data.

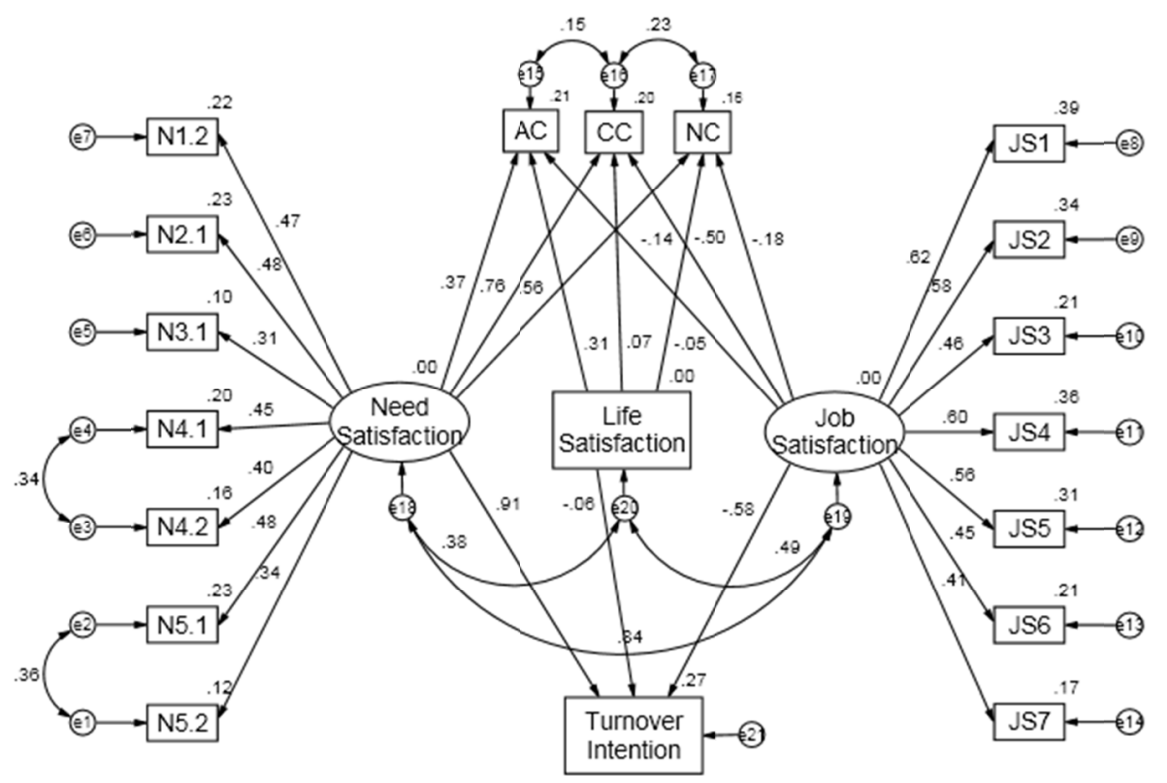

Figure 4. Final model of the relationships between need satisfaction, job satisfaction, life satisfaction, organizational commitment and turnover intention

Table 3. Model fit summary

\begin{tabular}{lcccc}
\hline Fit measures & Initial model & $1^{\text {st }}$ modification & $\begin{array}{c}2^{\text {nd }} \text { modification (final Acceptable fit } \\
\text { model) }\end{array}$ \\
\hline Discrepancy $\chi 2$ (CMIN) & 1146.325 & 754.412 & 361.920 & 0.000 \\
Degree of freedom (DF) & 271 & 258 & 138 & 0 \\
P & .000 & .000 & .000 & $1-3$ \\
Discrepancy $\chi$ 2/df (CMIN/DF) & 4.230 & 2.924 & 2.623 & $>.9$ \\
Goodness-of-Fit Index (GFI) & .805 & .865 & .913 & $>.8$ \\
Comparative Fit Index (CFI) & .573 & .758 & .841 & $>.8$ \\
Tucker-Lewis Index (TLI) & .528 & .719 & .802 & $>.8$ \\
Incremental Fit Index (IFI) & .579 & .763 & .844 & $0.05-0.08$ \\
Root Mean Square Error of Approximation & .090 & .069 & .064 & \\
(RMSEA) & & & & 184 \\
Hoelter .05 Index (HFIVE) & 109 & 157 & 198 & \\
Hoelter .01 Index (HONE) & 115 & 166 & & \\
\hline
\end{tabular}

The unstandardized regression coefficients for need satisfaction, job satisfaction, life satisfaction, affective commitment, continuance commitment, normative commitment and turnover intention are shown in Table 4. The need satisfaction items and job satisfaction items are all significant for the need satisfaction and job satisfaction latent variable. From the table, we can see that need satisfaction is positively significant for continuance commitment at the significance level $\alpha=0.01$. It is not surprising that need satisfaction is related to the "need" commitment of an employee. However, job satisfaction does not show any significant relationship with 
organizational commitment in the sample of Myanmar workers in Samut Sakhon. On the other hand, life satisfaction shows a significant positive relationship with affective commitment. Put simply, the more the employees' needs are satisfied, the more the commitment influenced by "need" increases, while an increase in employees' life satisfaction also shows an increase in their "emotional" commitment. Finally, in terms of calculating turnover intention in low-skilled Myanmar workers in Thailand, only need satisfaction shows a significant relationship with turnover intention. Interestingly, the direction of the relationship is positive, meaning that even though employees are satisfied that their needs are being met, they are nonetheless considering leaving. With these findings, hypotheses 1 and 5 are accepted, but hypotheses 2, 3, 4 and 6 are rejected.

Table 4. Unstandardized regression coefficients

\begin{tabular}{|c|c|c|c|c|c|c|}
\hline & & & Estimate & S.E. & C.R. & $\mathrm{P}$ \\
\hline $\mathrm{AC}$ & $\leftarrow$ & NS & 1.076 & .438 & 2.458 & .014 \\
\hline $\mathrm{CC}$ & $\leftarrow$ & NS & 2.206 & .620 & 3.560 & $* * *$ \\
\hline $\mathrm{NC}$ & $\leftarrow$ & NS & 1.604 & .514 & 3.119 & .002 \\
\hline $\mathrm{AC}$ & $\leftarrow$ & JS & -.242 & .253 & -.954 & .340 \\
\hline $\mathrm{CC}$ & $\leftarrow$ & JS & -.857 & .326 & -2.631 & .009 \\
\hline $\mathrm{NC}$ & $\leftarrow$ & JS & -.311 & .280 & -1.113 & .266 \\
\hline $\mathrm{AC}$ & $\leftarrow$ & LS & .317 & .059 & 5.385 & $* * *$ \\
\hline $\mathrm{CC}$ & $\leftarrow$ & LS & .072 & .071 & 1.013 & .311 \\
\hline $\mathrm{NC}$ & $\leftarrow$ & LS & -.048 & .064 & -.756 & .450 \\
\hline TI & $\leftarrow$ & NS & 2.748 & .738 & 3.726 & $* * *$ \\
\hline TI & $\leftarrow$ & JS & -1.050 & .379 & -2.772 & .006 \\
\hline TI & $\leftarrow$ & LS & -.062 & .078 & -.786 & .432 \\
\hline N5.2 & $\leftarrow$ & NS & 1.000 & & & \\
\hline N5.1 & $\leftarrow$ & NS & 1.346 & .207 & 6.502 & $* * *$ \\
\hline $\mathrm{N} 4.2$ & $\leftarrow$ & NS & 1.149 & .238 & 4.834 & $* * *$ \\
\hline N4.1 & $\leftarrow$ & NS & 1.330 & .260 & 5.119 & $* * *$ \\
\hline N3.1 & $\leftarrow$ & NS & .863 & .202 & 4.277 & $* * *$ \\
\hline $\mathrm{N} 2.1$ & $\leftarrow$ & NS & 1.355 & .256 & 5.288 & $* * *$ \\
\hline $\mathrm{N} 1.2$ & $\leftarrow$ & NS & 1.306 & .249 & 5.245 & $* * *$ \\
\hline JS1 & $\leftarrow$ & JS & 1.000 & & & \\
\hline JS2 & $\leftarrow$ & JS & 1.030 & .113 & 9.114 & $* * *$ \\
\hline JS3 & $\leftarrow$ & JS & .731 & .097 & 7.544 & $* * *$ \\
\hline JS4 & $\leftarrow$ & JS & .989 & .106 & 9.365 & $* * *$ \\
\hline JS5 & $\leftarrow$ & JS & .953 & .108 & 8.853 & $* * *$ \\
\hline JS6 & $\leftarrow$ & JS & .692 & .093 & 7.470 & *** \\
\hline JS7 & $\leftarrow$ & JS & .654 & .096 & 6.794 & $* * *$ \\
\hline
\end{tabular}

The standardized regression coefficients are shown in Table 5. These standardized regression coefficients make it possible to compare the size of the effect of the independent variable on the dependent variable. For need satisfaction, the highest load items are pay and fringe benefits. For the job satisfaction items, out of all the remaining seven items, five are hygiene factor items and two are motivator items. Thus, it is possible to say that to increase the effect that job satisfaction has on organizational commitment and turnover intention, employers need to focus on hygiene factors (pay, fringe benefits, supervisors, co-workers and the nature of the work), plus the motivators promotion and recognition. This is in agreement with a previous study by Khaleque and Rahman (1987), which found that specific aspects of a job, such as a good relationship with peers, a good working environment and job security, are the factors that exert a stronger influence on job satisfaction and commitment. 
Table 5. Standardized regression coefficients

\begin{tabular}{|c|c|c|c|c|c|c|c|}
\hline & & & Estimat & & & & Estimate \\
\hline $\mathrm{AC}$ & $\leftarrow$ & NS & .369 & $\mathrm{~N} 1.2$ & $\leftarrow$ & NS & .474 \\
\hline $\mathrm{CC}$ & $\leftarrow$ & NS & .760 & $\mathrm{~N} 2.1$ & $\leftarrow$ & NS & .485 \\
\hline $\mathrm{NC}$ & $\leftarrow$ & NS & .555 & N3.1 & $\leftarrow$ & NS & .314 \\
\hline $\mathrm{AC}$ & $\leftarrow$ & JS & -.139 & N4.1 & $\leftarrow$ & NS & .448 \\
\hline $\mathrm{CC}$ & $\leftarrow$ & JS & -.497 & $\mathrm{~N} 4.2$ & $\leftarrow$ & NS & .395 \\
\hline $\mathrm{NC}$ & $\leftarrow$ & JS & -.181 & N5.1 & $\leftarrow$ & NS & .480 \\
\hline $\mathrm{AC}$ & $\leftarrow$ & LS & .309 & N5.2 & $\leftarrow$ & NS & .343 \\
\hline $\mathrm{CC}$ & $\leftarrow$ & LS & .070 & JS1 & $\leftarrow$ & JS & .622 \\
\hline $\mathrm{NC}$ & $\leftarrow$ & LS & -.047 & JS2 & $\leftarrow$ & JS & .581 \\
\hline $\mathrm{TI}$ & $\leftarrow$ & NS & .906 & JS3 & $\leftarrow$ & JS & .459 \\
\hline TI & $\leftarrow$ & JS & -.583 & JS4 & $\leftarrow$ & JS & .603 \\
\hline \multirow[t]{3}{*}{ TI } & $\leftarrow$ & LS & -.058 & JS5 & $\leftarrow$ & JS & .560 \\
\hline & & & & JS6 & $\leftarrow$ & JS & .454 \\
\hline & & & & JS7 & $\leftarrow$ & JS & .406 \\
\hline
\end{tabular}

\section{Discussion and Conclusion}

The aim of this study is to examine the relationship between need satisfaction, job satisfaction and life satisfaction and employees' commitment and turnover intention among 400 Myanmar immigrants working in seafood processing factories in Samut Sakhon, Thailand. The results obtained from the research path diagram, using structural equation modelling, reveal interesting findings that are unique to this study group, providing additional evidence in support of findings in existing literature, as well as evidence that contradicts aspects of theory. The model and questionnaire used in this study were tested for reliability, validity and goodness of fit to ensure that the findings were sound. Although the chi-square test for model fit was significant, the other measures of goodness of fit provide support for the constructed model.

In support of previous literature, the results of this study reveal that need satisfaction and life satisfaction have positive relationships with organizational commitment. Specifically, need satisfaction has a particularly significant relationship with continuance commitment, whereas life satisfaction has a significant relationship with affective commitment. These results provide a better understanding of the factors that have a significant impact on employees' commitment: need satisfaction will lead to need-based (continuance) commitment, while life satisfaction will lead to emotion-based (affective) commitment. As affective commitment is regarded as one of the most powerful forms of commitment, companies should considered implementing strategies that focus on improving employee life satisfaction.

In the context of this study, job satisfaction did not show a significant relationship with organizational commitment. This is worth examining because job satisfaction has long been considered a dominant factor in understanding organizational commitment. For low-skilled workers, such as those in this study, the evidence contradicts the past literature, showing that job satisfaction does not relate to or exert an impact on employee commitment.

Of the three variables tested (need satisfaction, job satisfaction and life satisfaction), only need satisfaction demonstrated a significant relationship with turnover intention. Interestingly, the relationship is in a positive direction, in contradiction of the findings of past literature. This positive relationship means that an increase in need satisfaction will also mean an increase in turnover intention, signalling an alert to employers that the more employees' needs are satisfied, progressing up the levels of Maslow's hierarchy, the greater the chance that low-skilled workers will contemplate leaving. This interesting finding regarding turnover intention in low-skilled workers suggests the potential value of further study to examine the rationale behind turnover intention.

The significance of this study is that, to the author's knowledge, it is one of few studies to study the complex organizational behaviour of low-skilled workers, in this case Myanmar workers in Thailand. It is hoped that findings of this research can be employed to undertake further research and applied to other industries, as well as in other countries employing low-skilled workers. 


\section{Limitations and Future Research}

This research has several limitations that should be noted. First, this study focused on 400 Myanmar workers employed in the seafood processing industry located only in Samut Sakhon province. Therefore, to ensure the wider applicability of the findings it would be important to further validate the results with a more representative group of participants, expanding the research to other industries as well as other areas. Second, the questionnaire in this study necessarily included few items: to undertake further examination of organizational commitment and turnover intention in low-skilled workers, the inclusion of more items on these two variables would be beneficial and might reveal greater insights into the rationale behind employees' behaviour. Third, the study drew on predominantly Western literature, both in terms of the review and sourcing the items adopted in the questionnaire. Thus, there might be cultural differences that have not sufficiently been taken into account in relation to the items and the way in which the questionnaire was constructed. Finally, despite all the efforts made in translating the items, there might be language issues affecting how the Myanmar immigrants interpreted the statements.

Nonetheless, the study provides interesting results both supporting and challenges aspects in previous research. In future studies, the findings might be validated by expanding the number of respondents and undertaking research in other industries and areas. Moreover, the results could potentially be strengthened by constructing the questionnaire to have no neutral position, thus forcing respondents to take a position on whether they agree or disagree with the statements and providing more concrete conclusions.

\section{References}

Aamodt, M. G. (2007). Industrial/organisational psychology: An applied approach. Belmont, CA: Wadsworth Cengage Learning.

Ahmed, S. W., \& Alvi, S. A. (1987). Assessing organizational commitment in a developing country: Pakistan, a case study. Human Relations, 40(5), 267-280. http://dx.doi.org/10.1177/001872678704000502

Allen, N. J., \& Meyer, J. P. (1990). The measurement and antecedents of affective, continuance and normative commitment to the organization. Journal of Occupational Psychology, 63(1), 1-18. http://dx.doi.org/10.1111/j.2044-8325.1990.tb00506.x

Aworemi, J. R., Abdul-Azeez, I. A., \& Durowoju, S. T. (2011). An empirical study of the motivational factors of employees in Nigeria. International Journal of Economics and Finance, 3(5), 227-233.

Aydogdu, S., \& Asikgil, B. (2011). An empirical study of the relationship among job satisfaction, organizational commitment and turnover intention. International Review of Management and Marketing, 1(3), 43-53.

Barak, M. E., Nissly, J. A., \& Levin, A. (2001). Antecedents to retention and turnover among child welfare, social work and other human service employees: What can we learn from past research? A review and metanalysis. Social Service Review, 75, 625-661. http://dx.doi.org/10.1086/323166

Betz, E. L. (1984). Two tests of Maslow's theory of need fulfillment. Journal of Vocational Behavior, 24, 204-220. http://dx.doi.org/10.1016/0001-8791(84)90007-1

Bourantas, D. (1988). Leadership styles, need satisfaction and the organizational commitment of Greek managers. Scandinavian Journal of Management, 4(3-4), 121-134. http://dx.doi.org/10.1016/0956-5221(88)90004-8

Campbell, A., Converse, P. E., \& Rodgers, W. L. (1976). The quality of American life. New York: Russell Sage Foundation.

Cho, S., Johanson, M. M., \& Guchait, P. (2009). Employees intent to leave: A comparison of determinants of intent to leave versus intent to stay. International Journal of Hospitality Management, 28(3), 374-381. http://dx.doi.org/10.1016/j.ijhm.2008.10.007

Dawal, S. Z., Taha, Z., Ismail, Z. (2009). Effect of job organization on job satisfaction among shop floor employees in automotive industries in Malaysia. International Journal of Industrial Ergonomics, 39, 1-6. http://dx.doi.org/10.1016/j.ergon.2008.06.005

Dillman, D. (2000). Mail and Internet surveys: The tailored design method. New York: John Wiley.

Forde, C., \& MacKenzie, R. (2009). Employer's use of low-skilled migrant workers: Assessing the implications of human resource management. International Journal of Manpower, 30(5), 437-452. http://dx.doi.org/10.1108/01437720910977643

Freitas, F. A., \& Leonard, L. J. (2011). Maslow's hierarchy of needs and student academic success. Teaching and Learning in Nursing, 6, 9-13. http://dx.doi.org/10.1016/j.teln.2010.07.004 
Ghiselli, F. R., Lopa, L. J., \& Bai, B. (2001). Job satisfaction, life satisfaction, and turnover intent. Cornell Hotel and Restaurant Administration Quarterly, 42(2), 28-37.

Gieter, S. D., Hofmans, J., \& Pepermans, R. (2011). Revisiting the impact of job satisfaction and organizational commitment on nurse turnover intention: An individual differences analysis. International Journal of Nursing Studies, 48, 1562-1569. http://dx.doi.org/10.1016/j.jpurstu.2011.06.007

Hamel, S., Leclerc, G., \& Lefrancois, R. (2003). A psychological outlook on the concept of transcendent actualization. International Journal for the Psychology of Religion, 13(1), 3-15. http://dx.doi.org/10.1207/S15327582IJPR1301_02

Hayes, L. J., O’Brien-Pallas, L., Duffield, C., Shamian, J., Buchan, J., Hughes, F., Laschinger, H. K. S., North, N., \& Stone, P. W. (2006). Nurse turnover: A literature review. International Journal of Nursing Studies, 43, 237-263. http://dx.doi.org/10.1016/j.ijnurstu.2005.02.007

Herscovitch, L., \& Meyer, J. P. (2002). Commitment to organizational change: Extension of a three-component model. Journal of Applied Psychology, 87, 474-487. http://dx.doi.org/10.1037/0021-9010.87.3.474

Herzberg, F. (1991). Motivation: Papers about organizational behavior and motivation, tr. N. Janidi. Tehran: State Management Educational Center.

Herzberg, F. (1996). Work and the nature of man. Cleveland, OH: World Publishing Company.

Herzberg, F., Mausner, B., \& Bloch Snyderman, B. (2005). The motivation to work. New Jersey: Transaction Publishers.

Iqbal, A. (2010). An empirical assessment of demographic factors, organizational ranks and organizational commitment. International Journal of Business and Management, 5(3), 16-27. http://dx.doi.org/10.5539/ijbm.v5n3p16

Jaros, S. (1997). An assessment of Meyer and Allen's (1991) three-component model of organizational commitment and turnover intentions. Journal of Vocational Behavior, 51, 319-337. http://dx.doi.org/10.1006/jvbe.1995.1553

Judge, T. A., Thoresen, C. J., Bono, J. E., \& Patton, G. K. (2001). The job satisfaction-job performance relationship: A qualitative and quantitative review. Psychological Bulletin, 127(3), 376-407. http://dx.doi.org/10.1037/0033-2909.127.3.376

Kacmar, K., Carlson, D., \& Brymer, R. (1999). Antecedents and consequences of organizational commitment: A comparison of two scales. Educational and Psychological Measurement, 59(6), 976-994. http://dx.doi.org/10.1177/00131649921970297

Kalliath, T. J., \& Beck, A. (2001). Is the path to burnout and turnover paved by a lack of supervisory support? A structural equations test. New Zealand Journal of Psychology, 30, 72-78.

Khanin, D. (2013). How to reduce turnover intentions in the family business. Business Horizons, 56(1), 63-73. http://dx.doi.org/10.1016/j.bushor.2012.09.005

Khatri, N., Fern, C. T., \& Budhwar, P. (2001). Explaining employee turnover in an Asian context. Human Resource Management Journal, 11(1), 54-74. http://dx.doi.org/10.1111/j.1748-8583.2001.tb00032.x

Kramer, M. W., Callister, R. R., \& Turban, D. B. (1995). Information-receiving and information-giving during job transitions. Western Journal of Communication, 59, 70-151. http://dx.doi.org/10.1080/10570319509374513

Lumley, E. J., Coetzee, M., Tladinyane, R., \& Ferreira, N. (2011). Exploring the job satisfaction and organizational commitment of employees in the information technology environment. Southern African Business Review, 15, 100-118.

Mahdi, A. F., Mohd Zin, M. Z., Mohd Nor, M. R., Skat, A. A., Abang Naim, A. S. (2012). The relationship between job satisfaction and turnover intention. American Journal of Applied Sciences, 9(9), 1518-1526. http://dx.doi.org/10.3844/ajassp.2012.1518.1526

Maslow, A. H. (1954). Motivation and personality (3rd ed.). New York: Longman.

Maslow, A. H. (1968). Toward a psychology of being (2nd ed.). New York: D. Van Nostrand Company.

Maslow, A. H. (1970). Motivation and personality (2nd ed.). New York: Harper and Row.

McMahon, B. (2007). Organizational commitment, relationship commitment and their association with 
attachment style and locus of control. Partial fulfilment of Master of Science Degree in Psychology, Georgia Institute of Technology.

Meyer, J. P., \& Allen, N. J. (1991). A three-component conceptualization of organizational commitment. Human Resource Management Review, 1(1), 61-89. http://dx.doi.org/10.1016/1053-4822(91)90011-Z

Meyer, J. P., \& Allen, N. J. (1997). Commitment in the workplace. Thousand Oaks, CA: SAGE Publications.

Meyer, J. P., Stanley, D. J., Herscovitch, L., \& Topolnytsky, L. (2002). Affective, continuance and normative commitment to the organization: A meta-analysis of antecedents, correlates, and consequences. Journal of Vocational Behavior, 61, 20-52. http://dx.doi.org/10.1006/jvbe.2001.1842

Mowday, R., Steers, R., \& Porter, L. (1979). The measurement of organizational commitment. Journal of Vocational Behaviour, 14, 224-247. http://dx.doi.org/10.1016/0001-8791(79)90072-1

Price, J. L., \& Mueller, C. W. (1981). A causal model of turnover for nurses. Academy of Management Journal, 24, 543-565. http://dx.doi.org/10.2307/255574

Puangyoykeaw, K. (2014). Myanmar in Thailand: An empirical study of the relationship among the job characteristics model, job satisfaction, organizational commitment, and turnover intention in low-skilled workers. Journal of Social Science Research, 6(2), 1017-1028.

Puangyoykeaw, K., \& Nishide, Y. (2014). Needs perception, position, and contentment: An empirical study of Myanmar immigrant workers in Thailand. European Journal of Business and Social Sciences, 3(4), 93-101.

Rajasekhar, T., \& Vijayasree, K. (2012). Need satisfaction and job satisfaction of managerial professionals. International Journal of Engineering Research \& Technology, 1(9), 1-10.

Robbins, S. (1993). Organizational behaviour: Concepts, controversies, and applications (6th ed.). New Jersey: Prentice Hall.

Saari, L., \& Judge, T. (2004). Employee attitudes and job satisfaction. Human Resource Management, 43(4), 395-407. http://dx.doi.org/10.1002/hrm.20032

Salami, S. O. (2008). Demographic and psychological factors predicting organizational commitment among industrial workers. Anthropologist, 10, 31-38. http://dx.doi.org/10.1037/0021-9010.93.1.70

Solinger, O. N., van Olffen, W., \& Roe, R. A. (2008). Beyond the three-component model of organizational commitment. Journal of Applied Psychology, 93, 70-83.

Spector, P. E. (1985). Measurement of human service staff satisfaction: Development of the job satisfaction survey. American Journal of Community Psychology, 13, 693-713. http://dx.doi.org/10.1007/BF00929796

Spector, P. E. (1996). Industrial and organizational psychology. New York: John Wiley \& Sons.

Spector, P. (2008). Industrial and organisational behavior (5th ed.). New Jersey: John Wiley \& Sons.

Thailand Development Research Institute. (2007). A study of an effective demand for and management of alien worker in agriculture, fisheries and related sectors and construction sectors. Bangkok: Thailand Development Research Institute.

Velickovic, V. M., Visnjic, A., Jovic, S., Radulovic, O., Sargic, C., Mihajlovic, J., \& Mladenovic, J. (2014). Organizational commitment and job satisfaction among nurses in Serbia: A factor analysis. Nursing Outlook, 62(6), 415-427. http://dx.doi.org/10.1016/j.outlook.2014.05.003

Westlund, S., \& Hannon, J. (2008). Retaining talent: Assessing job satisfaction facets most significantly related to software developer turnover intentions. Journal of Information Technology Management, 19(4), 1-15.

Wright, P. (1989). Motivation and job satisfaction. In C. Molander (Ed.), Human resource management. Lund, Sweden: Studentlitteratur.

Van Breugel, G., Van Olffen, W., \& Ollie, R. (2005). Temporary liaisons: The commitment of 'temps' toward their agencies. Journal of Management Studies, 42(3), 539-566. http://dx.doi.org/10.1111/j.1467-6486.2005.00508.x

Yamane, T. (1967). Statistics: An introductory analysis (2nd ed.). New York: Harper and Row.

Yucel, I. (2012). Examining the relationship among job satisfaction, organizational commitment, and turnover intention: An empirical study. International Journal of Business and Management, 7(20), 44-58. http://dx.doi.org/10.5539/ijbm.v7n20p44 


\section{Copyrights}

Copyright for this article is retained by the author(s), with first publication rights granted to the journal.

This is an open-access article distributed under the terms and conditions of the Creative Commons Attribution license (http://creativecommons.org/licenses/by/3.0/). 